\title{
Sediment Drifts and Cold-Water Coral Reefs in the Patagonian Upper and Middle Continental Slope
}

\author{
A. Muñoz ${ }^{1 *}$, J. Cristobo ${ }^{2}$, P. Rios ${ }^{3}$, M. Druet ${ }^{4}$, V. Polonio ${ }^{5}$, E. Uchupi ${ }^{6}$, J. Acosta ${ }^{7}$, \\ and Atlantis Group**
}

1) Tragsa-SGM. Alcala 265, 28027, Madrid (Spain) Email: amur@tragsa.es. Phone: 34917822620; Fax: 34917821984

2) Instituto Español de Oceanografía. Centro Oceanográfico de Gijón, C/ Príncipe de Asturias 70 bis, 33212 Gijón, Asturias, Spain. E-mail: cristobo@gi.ieo.es

3) ) Instituto Español de Oceanografía. Centro Oceanográfico de Gijón, C/ Príncipe de Asturias 70 bis, 33212 Gijón, Asturias, Spain. E-mail: pilar.rios@gi.ieo.es

4) Instituto Español de Oceanografía. Corazón de Maria 8, 28002 Madrid. Email: maria.druet@md.ieo.es

5) Instituto Español de Oceanografía. Centro Oceanográfico de Gijón, C/ Príncipe de Asturias 70 bis, 33212 Gijón, Asturias, Spain. E-mail: virginia.polonio@gi.ieo.es

6) Woods Hole Oceanographic Institution. Woods Hole, Ma. 02543 USA. Email: elazaruchupi@movistar.es

7) Instituto Español de Oceanografía. Corazón de Maria 8, 28002 Madrid. Email: juan.acosta@md.ieo.es

*) Corresponding author

**Atlantis Group: S. Iglesias, J. Portela, J.L del Río, S. Parra, M. Sacau, R. Vilela, T. Patrocinio, B. Almón, E. Elvira, P. Jiménez, A. Fontán, C. Alcalá and V. López.

\section{ABSTRACT}

The north flowing Falkland / Malvinas Current has generated sediment drifts at a depth of 1200-1600 m in the Patagonian middle continental slope out of early Holocene hemipelagics, late Pleistocene ice rafted clastics, and Neogene fluvial sediments. Possibly there may be two generations of drifts, Pleistocene on the outer middle slope and Holocene on the inner shelf. The ice rafted debris originated in Antarctica, at a distance of 2000 to $4000 \mathrm{~km}$ south of Patagonia. Scattered over the upper and middle slopes, at depths ranging from 300 to $1400 \mathrm{~m}$, are cold-water coral reefs of less than a meter to about ten of meters in relief. It is inferred that most of cold-water coral structures flourish as a consequence of the Falkland /Malvinas Current that concentrates the food supply at the reef sites. Growth of cold-water coral reefs, documented by digital submarine photographs on the upper slope, at a depth of 300/400 m, may be promoted by upwelling 
of nutrient-rich waters and associated plankton blooms created by the intrusion of Falkland /Malvinas Current onto the outer shelf.

Keywords: Patagonian continental slope, Sediment Drifts, Falkland /Malvinas Current, Cold-Water Coral Reefs, Iceberg Rafted Sediments.

\section{Introduction}

Sediment drifts are formed by contour-following currents generated by thermohaline circulation (Faugères and Stow, 1993, Viana, 2001, Faugères et al., 2008). Frequently associated with the sediment drifts, erosional features as terraces, abraded surfaces, channels, moats and furrows are observed in areas where the currents are unusually strong (Hernández-Molina et al., 2010).

We follow in this paper the definition by Faugères et al. (1999; see also Rebesco and Stow, 2001; Faugères and Stow, 2008) who recognized seven types of drift geometry. They are: 1 . Sheeted drifts characterized by low relief and large lateral extent; 2. Mounded elongate drifts characterized by moderate to high relief and variable extent and detached elongate to irregular small-scale patch mounds; 3. Channel-drifts that occur within channels/moats, fans at channel mouths and channel levee drifts; 4.

Confined drifts in actively subsiding basins or troughs; 5 . Infill drifts with moderate relief and relatively small extent infilling the head of slump scars and the margins and toes of slumps; 6. Mixed drifts that include turbidite-sediment drift, debrite-sediment drift, hemipelagic-sediment drift, glaciogenic-sediment drift systems; 7. Fault-controlled drifts generated in response to fault generated basement relief and subsequent syndepositional fault reactivation.

Current-generated deposits on the Patagonian Argentine continental margin occur from shore to the deep-sea. Viana et al. (1998) classified current-generated deposits in depth of less than $300 \mathrm{~m}$ as shallow-water bottom-current sands and deeper than $300 \mathrm{~m}$ as sediment drifts. The deposits on the 320 to $500 \mathrm{~km}$ wide shelf are the result of a broad northeast flow of cold water that intensifies toward the shelf edge where it merges with the northeast flowing Falkland / Malvinas Current. Sedimentation on the upper and 
middle continental slope is under the influence of the northeast flowing Falkland / Malvinas Current.

Also associated with areas of accelerated deep-water currents on the Patagonian middle continental slope are cold-water coral reefs. Cold-water coral ecosystems are among the richest biodiversity hotspots in the deep sea, providing shelter and food for hundreds of associated species, including commercial fish and shellfish as in Sula Ridge in Norwegian waters (Fosså et al., 2000), and Gully, off Nova Scotia, Canada (Harrison and Fenton, 1998). In this paper we use the term reef, as defined by Davies et al. (2008), as biogenic structures that influence sediment deposition, provide complex structural habitats and are subject to the process of growth and (bio) erosion. These reefs can be over $40 \mathrm{~m}$ high, have lengths of several kilometers and occur at depths of less than $200 \mathrm{~m}$ to over $2800 \mathrm{~m}$; mean depths of 468 and $480 \mathrm{~m}$ (Freiwald et al., 2004; Roberts et al., 2006; Davies et al., 2008).

The first objective of this paper is to describe the internal geometry and potential controlling factors of sediment drifts. The second objective of the paper is to describe the occurrence and distribution of cold-water corals and cold-water coral reefs associated with the Falkland / Malvinas Current.

\section{Background}

\subsection{Seafloor morphology}

Hernández-Molina et al. (2010) ascribe the giant, elongated, and mounded sediment drift on the lower slope to a loop of the Antarctic Bottom Deep Water from the EoceneOligocene boundary to the middle Miocene during the opening of the Drake Passage. A change in the oceanographic conditions in mid-to late Miocene led to the fossilization of the drifts. Extension of North Atlantic Deep Water circulation into the southern Hemisphere and deepening of Antarctic Bottom Water circulation at that time led to the establishment of the present sediment drift sedimentary cycle and the creation of the present morphology of the lower slope. 
According to Viana et al. (1998) the composition of mid-water drifts varies from siliciclastic to bioclastic sands that may be inter-bedded with hemipelagics. The drifts of the Patagonian margin are mainly siliciclastic. They consist of mud, muddy sands, sandy muds and pebbly muds (Ewing and Lonardi, 1971; Portela et al. 2012, Parra et al., 2010). Thus, the mid-water drifts on the Patagonian middle slope are composed of hemipelagic mud and ice rafted debris.

Hernández-Molina et al. (2010) named Nágera Terrace the terrace extending from the base of the upper slope to a depth of 940 to $1060 \mathrm{~m}$, and whose western edge is scarred by late Pleistocene iceberg ploughmarks (López-Martínez et al. 2011). The terrace extending from a depth of about 1200 to 1600 m was called "Perito Moreno Terrace” by Hernández-Molina et al. (2010). A 100 to 280 m high scarp at which base is an 11401210 m deep moat separates the Nágera and Perito Moreno terraces. The Piedra Buena terrace is flanked on its seaward by the Valentin Feilberg terrace at a depth of 3500-4000 m.

\subsection{Lithology}

Eocene sediments were cored from a bench, from a canyon and from a smooth gently sloping seafloor with undulations at $1164 \mathrm{~m}$. Miocene sediments were recovered from a uniform bottom at $2736 \mathrm{~m}$, on the west wall of Almirante Canyon and in a step-like change in topography at $5124 \mathrm{~m}$ (Ewing and Lonardi, 1971). Paleocene sediments cored on the continental slope and rise are mainly glauconitic sands, the Eocene sediments forming a nearly continuous outcrop between 900 to $2500 \mathrm{~m}$ that consists of accumulations of benthic diatoms (diatomites) on the south suggesting that the section of the slope originates in shallow water, and carbonate facies on the north; the Miocene and Pliocene consist of pelagic sediments (Burckle and Hays, 1974). According to Hanna et al. (1976), the Eocene diatom frustules are not broken and are well preserved indicating that are in place and they were not reworked.

A core recovered from $41^{\circ} 30^{\prime} \mathrm{S}, 56^{\circ} 36^{\prime} \mathrm{W}$ from a topographic bench at a depth of $1414 \mathrm{~m}$ consisted of $15 \mathrm{~cm}$ Pleistocene rippled coarse granules indicative of strong currents resting on Eocene lutite. From this, Ewing and Lonardi (1971) inferred that the presence 
of Eocene so close to the seafloor was an indication of heavy erosion or non-deposition since the Eocene at the site.

At another core site $\left(45^{\circ} 27.9^{\prime} \mathrm{S} ; 59^{\circ} 40.1^{\prime} \mathrm{W}\right)$ on the middle slope, Eocene sediments also were recovered from a depth of $1044 \mathrm{~m}$ on the side wall at the head of Canyon 4.

Sediment data obtained in the study area showed that fine sands were generally predominant throughout the area, with low contents of organic matter and sediment sorting varying from poor to moderately good (Portela et al. 2012).

\subsection{Oceanography}

The circulation on the Patagonian shelf is a two-layer system with the flow of the upper layer being northeastward and the bottom layer toward the southwest (Matano et al., 2010). The sand ridges in water depth of less than $40 \mathrm{~m}$ and trending North-South are active and are formed by a north flowing current with an offshore component near the bottom (Parker et al., 1982). The gravelly sand ridges at a depth of $>100 \mathrm{~m}$, oriented oblique to the shelf edge and separated by 3 to $4 \mathrm{~km}$ wide troughs opened to the southwest do not appear to be active and are probably related to the time when sea level was much lower.

The Falkland / Malvinas Current extends from the sea surface to the ocean floor and its flow is strongly controlled by the bottom morphology (Piola and Matano, 2001). Within the current, at depths shallower than $1000 \mathrm{~m}$, is the northeast flowing Antarctic Intermediate Water (AAIW) and from a depth of $1000 \mathrm{~m}$ to 2000/2200 m is the northeast flowing Upper Circumpolar Deep Water (UCDW). Deposition on the Patagonian upper and middle continental slope is influenced by the northeasterly flowing $100 \mathrm{~km}$ wide Falkland / Malvinas Current (Matano et al., 2010). A chlorophyll maximum, that follows the western edge of the Falkland / Malvinas Current along the $200 \mathrm{~m}$ isobath, is the result of frictionally driven intrusions of the upper Falkland / Malvinas Current onto the shelf (Matano and Palma, 2008; Matano et al., 2010). These intrusions (Fig. 1) generate a shelf edge pressure gradient and a secondary-cross shelf divergence cell that in turn leads to upwelling along the shelf edge. 


\subsection{Cold-water Corals}

Cold-water coral ecosystems are among the richest biodiversity hotspots in the deep sea, providing shelter and food for hundreds of associated species, including commercial fish and shellfish as in Sula Ridge in Norwegian waters (Fosså et al., 2000); Gully, off Nova Scotia, Canada (Harrison and Fenton, 1998). Prior to our investigation the occurrence of cold-water corals in the Patagonian margin was poorly documented. No such coral reefs have been reported on recent compilations of world-wide deep water corals (Freiwald 2002, Freiwald et al., 1997, Freiwald et al., 2004 and UNEP, 2005). Yet Ewing and Lonardi (1971) photographed colonies at $41^{\circ} 30^{\prime} \mathrm{S} ; 56^{\circ} 36^{\prime} \mathrm{W}$ at a depth of $1409 \mathrm{~m}$. In general, coral reefs form topographic highs by skeletal framework accretion which is enhanced by biological encrustation over dead corals zones, prolific sediment production and concurrent inorganic or biologically-controlled cementation (Freiwald, 2002). Although Ewing and Lonardi (1971) reported the presence of cold-water corals off Argentina at $41^{\circ} 30^{\prime} \mathrm{S} ; 56^{\circ} 30^{\prime} \mathrm{W}$ at a depth of $1409 \mathrm{~m}$, the southernmost occurrence of cold-water corals (Freiwald et al., 2004; Davis et al., 2008) in the western South Atlantic is generally considered to be off Brazil. The largest cold-water coral reefs were found in the Patagonian continental slope, where they display a great density of individuals and associated fauna (Proyecto ATLANTIS, 2009, Cristobo et al., 2010a, b).

\section{Methods}

The morphology of the Argentine Patagonian margin was mapped aboard the R/V Miguel Oliver, of the Spanish Secretariat General of the Sea (SGM), in 2007 and 2008. During the cruises Patagonia-1107, Patagonia-1207, Patagonia-0108, Patagonia-0208, Atlantis-

0308, Patagonia-1008, Patagonia-1108 and Patagonia-1208, lasting 179 days, 33,984 km² of the seafloor off Patagonia were mapped from $44^{\circ} 40^{\prime} \mathrm{S}$ to $47^{\circ} 51^{\prime} \mathrm{S}$ and $58^{\circ} 52^{\prime} \mathrm{W}$ to $61^{\circ} 05^{\prime} \mathrm{W}$ (Fig. 1A). Navigation during the investigation of the Patagonian margin was via a differential GPS Simrad GN33 using satellite corrections from a Fugro system integrated in a MDM 400 software package with an inertial integrated aided Seapath 200 System. 
A Simrad EM-302 (30 kHz) multi-beam system was used to map the margin. The EM 302 echosounder system emits a fanned arc composed of up to 432 individual beams, each with a width as narrow as one vertical degree by one horizontal degree, with a possible swath angle of $150^{\circ}$. Using advanced processing techniques, a vertical resolution of $0.25 \%$ of the water depth can be achieved for features that span a horizontal distance of about $10 \%$ of the water depth, the average beam footprint size.

Information on the shallow structure of the margin was obtained with a hull mounted Topas PS18 high-resolution parametric profiler system, with integrated transmitter and receivers. A total of 89,363 km of geophysical profiles were recorded in the margin using the Topas system with line spacing of 1 to $3 \mathrm{~km}$.

The samples of benthic fauna collected in the study area have been obtained on one hand, prospecting in specific surveys with a rock dredge (58 stations), and secondly with a bottom trawl net over soft bottoms during fishing operations.

Samples for sedimentological studies were collected with a megabox corer dredge, designed to take undisturbed samples from the top of the seabed. A total of 156 samples were recovered.

In addition, a total of 1451 bottom photographs were acquired at 13 stations on the continental shelf and slope with a Nikon D700 digital camera with a >12 Mpixel sensor. Based on the distance between two red lasers points reflected on the seafloor individual photographs covered an area of 2 by $1.5 \mathrm{~m}$.

\section{Results}

The segment of the Argentine Patagonian continental slope investigated during the present study is made up of three topographic elements, an upper, a middle and lower slope. The upper continental slope dips $2^{\circ}$ and spans depths of $128 / 200 \mathrm{~m}$ to 250 to $750 \mathrm{~m}$ with its lower part being scarred by iceberg ploughmarks. The middle slope has an inclination of less than $1^{\circ}$ and a depth of $250 / 750 \mathrm{~m}$ to about $1600 \mathrm{~m}$, consists of two terraces: the Nágera Terrace extending from the base of the upper slope to a depth of 600 to $1060 \mathrm{~m}$ and the Perito Moreno Terrace, extending from a depth of about 1200 to 1600 
m. A 100 to $280 \mathrm{~m}$ high scarp at whose base is an 1140-1210 m deep moat, separates the Nágera and Perito Moreno terraces (Fig. 1A and Table I).

The Nágera Terrace ends southward at a $47^{\circ} 20^{\prime} \mathrm{S}$ against a northeast-southwest trending zone of folds, mud volcanoes and diapirs. We name its topset surface "South Nágera Terrace” (Fig. 1A).

\subsection{Sediment Drifts on the Patagonian Margin}

Examples of bottom controlled sedimentation along the east side of Perito Moreno Terrace south of $47^{\circ} \mathrm{S}$ are illustrated in the seismic profiles in Fig. 2 (see Fig. 1B for location of the profiles). This section of the terrace is characterized by N-S trending benches whose surfaces range from grooved to smooth (Fig. 1A). Along a N-S trending seismic profile (Fig. 2A), the sediment drift displays a plastered geometry divided in two by an unconformity. The drift above the unconformity is wellstratified (I, in Fig. 2A) whereas the lower unit (II, in Fig. 2A) displays geometry of cut and fill resting on a strong reflecting horizon (U, Fig. 2A). The acoustic transparent columns cutting the drift appear to originate in this reflector.

The profile in figure 2B displays a plastered drift affected by erosion. These erosional features cut on the scarp separating the Perito Moreno Terrace on the middle continental slope from the Piedra Buena terrace on the lower continental slope. Measurements of the scarp are summarized on Table I. The ridges and troughs (Fig. 2B), lie on a strong reflecting horizon terminating on a $100 \mathrm{~m}$ high rising from the strong reflecting horizon. The drift along the slope separating the Perito Moreno and Piedra Buena terraces is well stratified, has a maximum thickness of $100 \mathrm{~m}$ (Table I), and is elongate parallel to the current direction (Fig. 2B). This type of drift is classified as a separated drift. An unusual drift section occurs on a narrow depression in the eastern end of Canyon 0 (measurements on table I). The surface of the drift (Fig. 2C) north of the periphery of the depression is undulating displaying stratification with the strata and the strong reflecting horizon on which they rest terminating abruptly on the edges of the depression. The drift north of the depression is stratified, with its undulating surface bulging upward. This is 
further indication that the steps along the east side of the Perito Moreno Terrace are current generated.

In the area of Canyon 2, the profile parallel to the northern rim images benches that dominate the slope descending from Perito Moreno Terrace on the middle slope to Piedra Buena on the lower slope (Fig. 3A). The uppermost bench has an irregular surface capped by a plastered drift. The northeast end of the profile images a rough terrain that may reflect bottom current activity. At the northern end of figure 3B, located along one of the benches, there is a low filled with sediment drift and an infill drift, displaying a maximum thickness greater than $100 \mathrm{~m}$

The seismic section across a low along the eastern edge of the Perito Moreno Terrace north of Canyon 2 (Fig. 3C) images a drift whose geometry ranges from a plastered sediment drift at its southern end, to detached drifts in the center, and plastered and detached drifts at its northern end. The drift is divided in two by a low and rests unconformably on a strong reflecting horizon.

The moat separating the Nágera and Perito Moreno terraces (Fig. 4A) is asymmetrical in cross sections with its steep side on its east side. Within the moat are highs that may represent a sediment ridge. Along its northeast side are two highs with rounded tops that may represent mud diapirs. Forming the surface of the Perito Moreno Terrace is a plastered drift resting on an irregular reflector that may represent the top of Eocene lutites.

In the divide between canyons 2 and 3, the profile in Fig. 4B shows morphology of two sharp peaks, a rounded crested high and three "V" shaped lows. The sharp peaks display a sequence consisting of a lower homogeneous section capped by a stratified one with the southern flank of the central peak being covered by a plastered drift. The rounded high lacks bedding and its surface is highly reflective as are the adjacent low and the rolling terrain north of the low. This strong reflector forms the core of the sharp crested highs to the north. The ridge-trough is clearly imaged in 3D of the area of the seismic profile constructed from multi-beam data (Fig. 4D). This image indicates that the depressions in Fig. 4B probably are potholes eroded by bottom currents. 
Plastered drifts resting on the strong reflector also are illustrated by profiles in the divide between canyons 3 and 4 (Fig. 4C) and the slope descending from the Perito Moreno Terrace on the middle slope to the Piedra Buena on the lower slope.

Plastered drift mantles the seafloor and the divide between the south and north branches of Canyon 4 (Fig. 5A). The broad swell along the north side canyon 4 and the rest of the divide between canyons also are blanketed by plastered drifts. The acoustic stratigraphy of the swell, as imaged in Fig. 5B, is cut in two by vents (V); with the larger one terminating on a pockmark on the seafloor. This section is deformed along the flank of Canyon 4 by structures suggestive of mass wasting. The uppermost unit resting unconformably on the lower stratified one also is stratified and fills the tops of the vents. A plastered drift blankets the divide between canyons 5 and 6. There are gullies (Table I), that can be traced from the base of the upper slope to the eastern limit of the survey area (Fig. 1). Farther east the seafloor on the same divide displays a hummocky rough surface (Fig. 5C). We infer that this unit also is a plastered drift.

The most enigmatic feature on the Perito Moreno Terrace is a high NW-SE trending ridge (Table I), between canyons 1 and 2 (Fig. 6A). The sediment drift on either side of the ridge resembles a confined drift constrained by highs. The west side of the ridge has been buried to nearly its multi-peaked crest by a plastered drift (Fig. 6B). Sediment waves, several hollows and a moat at the base of the ridge characterize the drift west side of the ridge. A moat is also present on the east of the ridge with a maximum depth of $1350 \mathrm{~m}$ (Fig. 6C), and northeast of the moat is a sediment ridge, a detached drift, with a symmetrical profile in cross-section.

The central area of the ridge is asymmetrical in cross-section (Fig. 6D) with its east side being much steeper than its west side and its crest being less than $1000 \mathrm{~m}$ deep. The south part of the ridge (Fig. 6E) is symmetrical in cross-section and displays two peaks with depths of less than $1000 \mathrm{~m}$. Along both sides of the ridge, are moats eroded by bottom currents. Beyond the moat on the west side of the ridge is an inclined platform (Figs. 6D and E) mantled by a plastered drift whose SW end is intruded by a diapir (D, Fig. 6E).

\subsection{Cold-water Corals}


Prior to our investigation the occurrence of cold-water corals in the Patagonian margin was poorly documented. In the study area, the largest biomass of cold-water corals was located at depths between 400 and 1000 m, sometimes in low slope areas, forming both small aggregates and reefs few metres high.

The benthic megafauna caught during the cruises, showed dominance of the Phyla Cnidaria and Porifera, in terms of biomass (46\% and 30\%, respectively). The high abundance of the Phylum Cnidaria is of greater importance: $33.7 \%$ of the biomass of this Phylum belongs to the Class Octocorallia, including significant groups such as gorgonians, alcyonaceans and pennatulaceans.

During the present investigation photographic documentation and samples of cold-water corals were acquired on a hummocky area of the upper slope from $45^{\circ} \mathrm{S}$ to $45^{\circ} 30^{\prime} \mathrm{S}$, on the ridge south of Canyon 2 and on individual glacial erratics on the eastern edge of the Perito Moreno Terrace. Samples at stations scattered throughout the middle slope included also corals. After sampling the area with box corer, Lofoten fishing gear and rock dredge, the bottom photographs showed that the hummocky terrain on the upper slope at a depth of 300-500 m was populated by soft corals (octocorals, Fig. 7 A-C). The coral garden in this area is a dense aggregation of colonies or individual corals belonging to different taxonomic groups, and also includes a large number of invertebrate species. Different species of cnidarians (Primnoidae are dominant among Alcyonacea and Gorgonacea), bryozoans, ophiuroids (Gorgonocephalidae, Astrotoma sp., Ophiura (Ophyuroglypha) lymani (Ljungman, 1871)), Asteroidea (Henricia sp. and Family Solasteridae), Octopodidae, ascidians, and massive sponges and fishes as grenadier Macrourus carinatus (Günther, 1878) were observed. This biotic association meets the criteria for classification as vulnerable marine ecosystem because of large sponges make them very vulnerable to perturbations, particularly to the mechanical impact of bottom fishing activities. Once removed, they could take decades to recover (UNGA, 2006; FAO, 2008; Rogers and Gianni. 2009).

As imaged by two of the photographs taken at Station 9, the seafloor of the bench at the transition from the middle to the lower continental slope is characterized by sediment waves with skeletal fragments of invertebrates (mollusks, cnidarians) and angular to subrounded pebbles along the crests of the waves (Fig.7 D). The sediment, ice rafted debris 
transported northward by the Falkland / Malvinas Current, has undergone reworking since its deposition to form the sediment drifts blanketing the Perito Moreno Terrace. Apparently the ice rafted debris formed an armor over the Eocene lutite protecting it in places from erosion. However, where the Eocene strata are exposed they have undergone reworking.

Bottom photographs at the southeast end of the ridge south of Canyon 2 (Station 10, Fig. 1) indicate that this segment of the ridge is covered by cold-water corals (Bathelia candida Moseley, 1881) and very abundant carnivorous sponges (Chladorhizidae) mainly Euchelipliuma spp. and Cercicladia australis Ríos, Kelly, Vacelet, 2011 (Ríos et al. 2011) and Hydrozoans (Stylasteridae and Plumulariidae) (Figs. 7 E-F). Solenosmilia variabilis Duncan, 1873 was also found in minor quantities in the samples taken in the area.

As imaged by the photographs a colony of the scleractinian Bathelia candida is growing among lace corals (Family Stylasteridae; Stylaster densicaulis Moseley, 1879, Mopsea sp. or Sporadopora sp.). Under favorable environmental conditions, these scleractinian corals grow over generations and form dense populations and eventually form reefs or coral-rich grounds. Bathelia candida is the main reef builder species in the study area and grows on dead corals beds of the same species, building the complex three-dimensional habitat that provides a multitude of microniches for the associated animal community. Mature colonies can be divided into an upper living zone and a lower dead coral framework zone (Fig. 7E).

Other groups of the coral framework-associated community in figure $7 \mathrm{~F}$ are Paragorgiid and Primnoid gorgonians, in particular Plumarella sp., Covexella spp., Primnoella spp., Thouarella spp., Dasystenella sp., and Fannyella spp., among other taxa. Paragorgia sp. is another abundant sea fan growing on scleractinians, always of small or medium size depending on the substratum surface size and stability. Solitary corals (Caryophillia spp. Desmophyllum dianthus (Esper, 1794), Flabellum spp. and Javania spp.) together with tunicates, sponges, brachiopods and bryozoans were found. The distribution of stony and soft cold-water corals compiled from maps from Proyecto ATLANTIS (2009) is illustrated in Fig. 1A (yellow dots). 


\section{Discussion}

\subsection{Spatial distribution and controlling parameters of sediment drifts}

Sediment making up the drifts on mid-water depths is generally transported to the site, where it undergoes reworking by bottom currents, off-shelf spillover by wave and tidal processes, slump-slides, debris flows, ice-tongues and turbidity currents (Stow and Mayall, 2000). None of these processes are important today in the Patagonian margin. Faugères and Stow (2008) state that sand drifts in mid-water form extensive sheets on a variety of slope, bank and channel settings. Only the drifts north of Canyon 3 display wide sheet geometry and their thickness are in the order of several meters to over $10 \mathrm{~m}$. Faugères and Stow (2008) also stated that mid-water sediment drifts on the continental slope are proximal to continental sediment sources and are formed by currents with high velocity. The Patagonian drifts may have been reshaped by currents of high velocity. A fluvial input from continental sources only took place in the Pleistocene when sea level was lower and the shelf was exposed and in early Holocene when a rising sea transgressed the shelf. The shelf is too wide, hundreds of $\mathrm{km}$, for any modern sediment to reach the Patagonian continental slope from western continental sources by fluvial means. That no sediment is being deposited on the slope is supported by the state of preservation of the late Pleistocene iceberg ploughmarks field on the upper and middle continental slope (López-Martínez et al., 2011). Any modern hemipelagic terrigenous sediment accumulating on the slope can only come from the south, being carried to the site by the north flowing Falkland / Malvinas Current.

During late Pleistocene, when the shelf was exposed, the continental fluvial systems extended their courses to the outer shelf and deposited their loads on its edge. From there, gravitational processes led to its displacement into deeper water onto the slope via the canyons. Part of the sediment was deposited on the upper and middle slope, but the bulk of it was transported via the canyons beyond the middle slope. The slope also was a major sink of hemipelagics during the early Holocene. Off-shelf spillover transported the fines winnowed out of the sands onto the slope. Where the hemipelagic and glacial sediments have undergone lateral transport in the middle slope, the Eocene and possibly 
older sediments beneath may outcrop. Reworked sediments also fed the drifts. Hemipelagic sediments transported northward by the Falkland / Malvinas Current must have been a major component of the drifts in the Patagonian slope.

Provenance of sediments in drifts is from fluvial sedimentation in late Pleistocene when the shelf was exposed, spillover from the shelf during the Holocene, hemipelagics, icerafted debris supplied by processes as the Holocene rise in sea level and the northeasterly flowing 100 km wide Falkland / Malvinas Current.

The sediment drifts south of Canyon 2 (Fig. 8) are stratified and rest on a strong reflecting horizon, and display geometries ranging from plastered, exposed and buried mounds, drifts separated from highs by moats along which the principal bottom flow is concentrated and sediment waves along the outer edge of the Perito Moreno Terrace. The drifts on the scarp separating the Perito Moreno Terrace on the middle slope and the Piedra Buena Terrace on the lower slope (Fig. 8) are cut by troughs that are morphologically comparable to the furrows described by Flood (1983) and Fedele and García (2009). Flood (1983) ascribes the furrows in low seafloor slopes to helical motion in benthic boundary layers, and Fedele and García (2009) proposed that similar features on relatively steep submarine slopes are due to centrifugal instability that sets in interfaces of unconfined turbidity currents or other cascading dense flows. The features on the slope east of the Perito Moreno Terrace appear to be more compatible with the origin proposed by Fedele and García (2009).

South of Canyon 2 a drift occurs along the margins of a narrow depression east of Canyon 0, the depression appears to be surrounded by sediment drifts, but no such sediments are present within the low. Possibly the low was kept free of drift by eddies formed as the north flowing Falkland / Malvinas Current crossed the east-west trending low. Another explanation is that the low was formed after the deposition of the drift by the expulsion of fluid/gas. Such an explanation is not unrealistic as pockmarks are common in the region. Other bottom current generated features are the rills and chutes eroded on the face on the NW-SE trending ridge, the moat surrounding the ridge, the sediment drift on either side of the ridge and the hollows northwest of the ridge. The horizon on which the drifts south of Canyon 2 rest is the top of Eocene lutites. Where exposed, the lutites have undergone erosion by bottom currents giving rise to waves and 
mounds with crenulated tops. Rising from these lutites are acoustically transparent columns cutting the drift above. These features were probably formed by vented fluid/gas and appear to originate within the Eocene sediments.

The drifts north of Canyon 2 also appear to rest unconformably on Eocene strata that are exposed along the eastern edge of the Perito Moreno Terrace (Fig.8). The drifts have geometries buried and exposed mounds, plastered sheets with wavy tops, infills of circular depressions and along the heads of slumps, mantles over canyon divides and a fault controlled swell on the north side of Canyon 4. The sheets north of Canyon 3 that spread out across the Perito Moreno Terrace are a consequence of a gentle gradient and smooth morphology that favored a wide unconstrained bottom current. Possibly a scenario for the construction of the drifts could be as follows. The Falkland / Malvinas Current was diverted eastward during the glacially-induced drop in sea level in late Pleistocene. So, drifts along the eastern edge of the Perito Moreno Terrace were constructed and soon after cut by submarine canyons. During the Holocene deglaciation the Falkland / Malvinas Current migrated upslope to its present location leading to the renewal of erosion along the scarp separating the Perito Moreno and the Nágera terraces (Fig. 8). Coriolis Effect caused the north flowing current to deflect to the left, constraining the flow against the scarp separating the terraces. As a result of this constraint the flow intensified leading to erosion of the scarp and the enhancement of the moat at its base. Lower velocities to the right of the flow led to the deposition of the sheet drift blanketing the Perito Moreno Terrace between canyons 3 and 6 and over their tributaries.

\subsection{Spatial distribution and inferred origins of cold-water corals along the Patagonia margin}

The largest concentration of cold-water corals in the study area was located at depths between 400 and $1000 \mathrm{~m}$, forming both small aggregates and reefs of few metres. In our surveys, the most frequent of scleractinian species was Bathelia candida, exclusively distributed offshore southern South America, from Rio Grande (south Brazil) to south Chile (Cairns, 1982; Kithara et al., 2009). This species is less known than Lophelia pertusa (EUNIS codes A5.631 and A6.611), but ecologically also very important as 
bioconstructor. Solenosmilia variabilis was also found in minor quantities, but Lophelia pertusa or Madrepora oculata were not encountered.

The maps of Freiwald et al. (2004) showing the global occurrences of Lophelia pertusa, Madrepora oculata and Solenosmilia variabilis, and the map of Davies et al. (2008) showing the global distribution of Lophelia pertusa do not display the presence of coldwater corals off Argentina. Cold-water corals were found instead in the Patagonian continental slope displaying a great density of individuals and associated fauna (Proyecto ATLANTIS, 2009; Cristobo et al., 2010a, b).

Individual corals have been photographed on iceberg drop stones during ATLANTIS project deeper than $1400 \mathrm{~m}$. The sediment, ice rafted debris transported northward by the Falkland / Malvinas Current, has undergone and is undergoing reworking since its deposition to form the sediment drifts blanketing the outer edge of the Perito Moreno Terrace. Such an interpretation is supported by a core recovered by Ewing and Lonardi (1971) from the area of photograph station 9. Apparently the ice rafted debris has formed an armor over the Eocene lutite protecting it in places from erosion by the bottom currents. However, where the Eocene strata are exposed they have undergone reworking. The reefs are best developed along the base of the upper slope and on the crest of the ridge south of Canyon 2 (Fig.8). Mortensen et al. (2001) suggest the growth of these reefs is controlled by accelerated currents that concentrate the food supply at the reef site with the currents enhancing reef growth by reducing sedimentation. The origin of the reef associated with the ridge south of Canyon 2 and the individual corals on iceberg drop stones could be compatible with such scenario. Similarly, the bioherms on the upper slope also may be due to the upwelling of nutrient rich waters and associated plankton blooms created by the intrusion of Falkland / Malvinas current onto the outer shelf. Dullo et al. (2008) shows that cold-water corals in the North Atlantic tolerate a wide range of environmental conditions but living cold-water coral reefs occur within a density envelope ( 27.35 to $27.65 \mathrm{~kg} \mathrm{~m}^{3}$ ), thus highlighting the importance of physical boundary conditions for cold-water coral growth and distribution.

\section{Conclusion}


Large expanses of the Perito Moreno Terrace on the Patagonian middle slope at a depth of 1200 to $1600 \mathrm{~m}$ are mantled by sediment drifts sculptured out of early Holocene hemipelagics, late Pleistocene ice rafted clastics and fluvial sediments and Neogene / reworked Eocene sediments by the north flowing Falkland / Malvinas Current.

Scattered over the middle and upper slope are cold-water corals forming reefs of less than a meter to several meters in relief. The cold-water corals structures flourished as a consequence of currents that concentrate the food supply at the reef site. Growth of bioherms on the upper continental slope may be driven by the upwelling of nutrient rich waters and associated plankton blooms created by the intrusion of Falkland / Malvinas Current onto the outer shelf.

\section{Acknowledgements}

We are indebted to the Captain, officers and crew of R/V Miguel Oliver (Secretariat General of the Sea, SGM) for their efforts during the cruises to the Patagonian margin. We also wish to thank SGM, who provided the ship time and technical support and to the members of the Spanish Oceanographic Institute (IEO) who participated in the cruises. Gratitude also is expressed to the Cartography Group SGM-TRAGSA who participated in the different cruises and processed the multi-beam data.

We acknowledge to André Freiwald and two anonymous reviewers for the throughout revision of an early manuscript, that improved the final result. Thanks also to Nereo Preto associate editor of the journal for his revision and help.

Funding for this study was provided by IEO in collaboration with SGM. This paper is a contribution of the Atlantis Project. 


\section{References}

Burckle, L.H., Hays, J.D., 1974. Pre-Pleistocene sediment distribution and evolution of the Argentine continental margin and Falkland Plateau (Abs). Geol. Soc. America Annual Meeting, abstractys with Programs, 673-674.

Cairns, S.D., 1982. Antarctic and Subantarctic scleractinia. Biology of the Antarctic Seas XI. Antarctic Research Series, vol 34; Paper I, pp 1-74.

Cristobo, J. Portela, J. Acosta, J., Ríos, P., del Río, J.L., Muñoz, A., Parra, S., Patrocinio, T., Almón, B. Blanco, R., Polonio, V., 2010a. La investigación de los Ecosistemas Marinos Vulnerables en aguas internacionales del Atlántico Suroccidental y de las posibles interacciones con las actividades pesqueras: el proyecto ATLANTIS. XVI Simposio Ibérico de Estudios de Biología Marina. 6-10 Septiembre 2010, Alicante (España).

Cristobo, J. Acosta, J., Muñoz, A., Almón, B., Ríos, P., Portela, J., del Río, J.L., Parra, S., Patrocinio, T., Blanco, R., Polonio, V., 2010b . Estudio de hábitats bentónicos profundos mediante fotografía digital: de los jardines de coral a los corales de aguas frías. XVI Simposio Ibérico de Estudios de Biología Marina. 6-10 Septiembre 2010, Alicante (España).

Davies, A., Wisshak, M., Orr, J.C., Roberts, J.M., 2008. Predicting suitable habitat for cold-water coral Lophelia pertusa (Scleractinia). Deep-Sea Research I 55, 10481062.

Dullo W-C., Flögel S., Rüggeberg A., 2008. Cold-water coral growth in relation to the hydrography of the Celtic and Nordic European continental margin. Marine Ecology Progress Series 371, 165-176.

Ewing, M., Lonardi, A.G., 1971. Sediment transport and distribution in the Argentine Basin. 5. Sediment structure of the Argentina margin, basin, and related provinces. In: Ahrens, L.H., Press, F., Runcorn, S.K., Urey, H.C. (Eds.), Physics and Chemistry of the Earth 8. Pergamon Press, New York, pp. 123-251.

FAO., 2008. Consulta técnica sobre las directrices Internacionales para la ordenación de las Pesquerías de aguas profundas en alta mar. Roma (Italia), 4-8 de febrero de 2008. TC:DSF/2008/Inf.3. pp 33. 
Faugères, J-C., Stow, D.A.V., 1993. Bottom-current-controlled sedimentation: a synthesis of the sediment drift problem. Sedimentary Geology 82, 287-297.

Faugères, J.-C., Stow, D.A.V., 2008. Sediment drift drifts: nature, evolution and controls. In: Rebesco, M., Carmerlenghi, A. (Eds.), Sediment drifts, Developments in Sedimentology, v. 60, pp. 250-288.

Faugères, J-C., Stow, D.A.V., Imbert, P., Viana, A., 1999. Seismic features of sediment drift drifts. Marine Geology 162, 1-38.

Fedele, J.J., García, M.H., 2009. Laboratory experiments on the formation of subaqueous depositional gullies by turbidity currents. Martine Geology 258, 48-59.

Flood, R.D., 1983. Classification of sedimentary furrows and a model for furrow initiation and evolution. Geological Society of America Bulletin 94, 630-639.

Fosså, J.H., Mortensen, P.B., \& Furevik, D.M., 2000. Lophelia-korallrev langs Norskekysten forekomst og tilstand. Fisken og Havet 2-2000. Havforskningsinstituttet, Bergen.

Freiwald A., 2002. Reef-forming cold-water corals. In: Ocean Margin Systems (Eds G Wefer, D Billett, D Hebbeln, BB Jørgensen, M Schlüter, TCE van Weering), Springer, Heidelberg, pp. 365-385.

Friewald A, Henrick R, Pätzold J., 1997. Anatomy of a deep-water coral reef mound, Noway. In: James NP, Clarke JAD (Eds.) Cool-water carbonates. Society of Economic Paleontologists and Mineralogists Special Publication 56, 141-162

Freiwald, A., 2002. Reef-forming cold-water corals. Ocean Margin Systems. G. Wefer, Billett, D., Hebbeln, D., Jørgensen, B.B., Schlüter, M. and van Weering, T.C.E. Heidelberg, Springer, pp. 365-385.

Friewald A, Fossa, A, Grehan JH, Koslow T, Roberts JM., 2004. Cold-water reefs. UNEP-WCMC. Cambridge, UK.

Hanna, G.D., Hendey, I.N., Brigger, A.L., 1976. Some Eocene diatoms from South Atlantic cores. Calif. Acad. Sci. Occ. Papers, 123, pp. 26.

Harrison, W.G., Fenton, D.G., 1998. The Gully: A Scientific Review of its Environment and Ecosystem, Canadian Stock Assessment Secretariat Research Document, Department of Fisheries and Ocean, Ottawa, 98/83. 
Hernández-Molina, F.J., Patelini, M., Somoza, L., Violante, R., ArecCo, M.A., de Isasi, M., Rebesco, m., Uenzelmann, G., Neben, S., Masrshall, P., 2010. Giant mounded drifts in the Argentine continental margin: origins and global implications for the history of thermohaline circulation. Marine and Petroleum Geology 27, 15081530.

Kithara, M.V., Capítoli, R.R., Horn Filho, Norberto, O., 2009. Distribuição das espécies de corais azooxantelados na plataforma e talude continental superior do Sul do Brazil. Iheringia, Sér. Zool, Porto Alegre, 99 (3), 223-236

Legeckis, R., Gordon, A.L., 1982. Satellite observations of the Brazil and Falkland currents, 1975 to 1976 and 1978. Deep-Sea Research 29, 375-401.

López-Martínez, J., Muñoz, A., Dowdeswell, J.A., Linés, C., Acosta, J., 2011. Relict seafloor ploughmarks records deep-keeled Antarctic icebergs to $45^{\circ} \mathrm{S}$ on the Argentine margin. Marine Geology 288, 43-48.

Matano, R.P, Palma, E.D., 2008. On the upwelling of downwelling currents. Journal of Physical Oceanography 38, 2482-2500.

Matano, R.P., Palma, E.D, Piola, A.R., 2010. The influence of the Brazil and Malvinas currents on the southwestern Atlantic shelf circulation. Ocean Science Discussion Paper 7, pp. 837-871.

Mortensen, P.B., Hovland, M.T., Fossä, J.H., Furevik D.MN., 2001. Distribution, abundance and size of Lophelia Pertusa coral reefs in mid-Norway relation to seabed characteristics. Journal of the Marine Biological Association of the United Kingdom 83, 581-597.

Parker, G., Lafredi, N.W., Swift, D.J.P., 1982. Seafloor response to flow in a Southern Hemisphere sand-ridge field: Argentine inner shelf. Sedimentary Geology 33, 195-216.

Parra, S., Muñoz, A., Valencia, J., Vázquez, C., Fernández, J., Cristobo, J., Acosta, J., Portela, J., del Río, J.L., Vilela, R., Grupo ATLANTIS, 2010. Estudios endofaunales y sedimentológicos en aguas internacionales del Atlántico Suroccidental dentro del proyecto ATLANTIS: Resultados preliminares. XVI Simposio Ibérico de Estudios de Biología Marina. 6-10 Septiembre 2010, Alicante (España). 
Peterson, R.G., 1992. The Boundary Currents in the western Argentine Basin. DeepSea Research 39, 623-644.

Piola, A.R, Matano, R.P., 2001. Brazil and Falklands (Malvinas) currents. In Steele, J.M, Thorpe, S.A, Turekian K.K (eds.) Encyclopedia of Ocean Sciences. New York, Academic Press, pp. 340-349.

Portela, J., Acosta, J, Cristobo, J., Muñoz, A, Parra, S., Patrocinio, T., Del Río, J.L., Vilela, R., Ríos, P., Blanco, R., Almon, B.,Tel, E., Besada, V., Viñas, L., Polonio, V. Barba, M., Marín P., 2012. Management Strategies to Limit the Impact of Bottom Trawling on VMEs in the High Seas of the SW Atlantic, in: A. Cruzado (Ed.), Marine Ecosystems. InTech, 978-953-51-0176-5, chapter, 9, pp.199-228.

Proyecto ATLANTIS., 2009. Informe preliminar sobre Ecosistemas Marinos Vulnerables en aguas internacionales del Atlántico Sudoccidental y de las posibles interacciones con la actividad pesqueras. Programa Pesquerías Lejanas, Instituto Español de Oceanografía, Madrid, pp.157.

Rebesco, M., Stow, D., 2001. Seismic expression of sediment drifts and related deposits: a preface. Marine Geophysical Researches 22, 303-308.

Ríos, P., Kelly, M., Vacelet, J. 2011. Cercicladia australis, a new carnivorous sponge with novel chelae from the Tasman Basin and the Argentine Patagonian Margin (Porifera, Cladorhizidae). Zootaxa 3131, 52-62.

Roberts, J.M., Wheeler, A.J., Freiwald, A., 2006. Reefs of the deep: the biology and geology of cold-water coral systems. Science 214, 543-547.

Rogers, A., Gianni, M., 2009. The Implementation of UN Resolution 61/105 in the Management of Deep-Sea Fisheries on the High Seas. Provisional Report, North Atlantic: Status and Recommendations. International Programme on the State of the Ocean. London. November 2009.

Stow, D.A.V., Mayall, M., 2000. Deep-water sedimentary systems: new models for the $21^{\text {st }}$ century. Marine and Petroleum Geology 17, 125-135.

UNEP World Conservation Monitoring Centre., 2005. Global cold-water distribution (points), Cambridge, UK, UNEP-WCMC.

UNGA., 2006. Resolution 61/105. Sustainable fisheries, including through the 1995 Agreement for the Implementation of the Provisions of the United Nations 
Convention on the Law of the Sea of 10 December 1982 relating to the Conservation and Management of Straddling Fish Stocks and Highly Migratory Fish Stocks, and related instruments. Operative Paragraphs 80-91. UNGA A/RES/61/105.

Viana, A.R., 2001. Seismic expression of shallow-to deep water sediment drifts along the south-eastern Brazilian margin. Marine Geophysical Researches 22, 509-521.

Viana, A.R., Faugères, K.-C, Stow, D.A.V., 1998. Bottom-current sand deposits---a review of modern shallow-to deep-water environments. Sedimentary Geology $115,53-80$. 


\section{FIGURE CAPTIONS}

Figure. 1. A: Bathymetry of a segment of the Argentine Patagonian continental margin compiled from Multi-beam data. Contour interval $100 \mathrm{~m}$. Insert: Location of study area and extend of the Falklands/Malvinas and Brazil Currents on the Argentine Continental margin compiled from Legeckis and Gordon (1982) and Peterson (1992). 1. B: DTM of the Patagonian shelf and upper slope showing locations of seismic profiles and 3D figures. White dots $=$ Camera Stations; Yellow dots= Distribution of stony and soft coldwater corals; White starts= Cores by Ewing and Lonardi (1971).

Figure. 2. High-resolution seismic reflection profiles of sediment drifts along the eastern edge of the Perito Moreno Terrace. A. Profile along the hummocky slope west of the western step. B. High resolution of seismic refection profile of the sediment drift along the eastern edge of the Perito Moreno Terrace. Unconformity U may be the top of Eocene lutites. Turbidity currents may have eroded channels cut on the drift. In $2 \mathrm{C}$ the drifts pinch out to the north and terminate abruptly along the edges of the depression east of Canyon 0. Possibly the drift has not filled the depression as a consequence of eddies formed as the north flowing Falkland / Malvinas Current crossed the depression or the depression has been eroded out of the drift by the expulsion of gas/fluid See Fig. 1B for locations of profiles.

Figure. 3. High-resolution seismic reflection profiles in the vicinity of canyons 1 and 2 along the eastern edge of the Perito Moreno Terrace. A. Profile displaying the series of steps along the eastern edge of the Perito Moreno Terrace. The steps are probably carved in sediment drift. A younger drift caps the surface of the western step. B. Features imaged by this profile included a formed topographic low filled with sediment drift on the North side and the northern rim of Canyon 2 eroded by bottom currents. The pinnacles on the southern rim of the canyon may owe their morphology to bottom currents and carbonate accretion. C. Plastered and detached drifts filling a formed topographic low north of Canyon 2. See Fig. 1B for location of profiles.

Figure. 4. A. Plastered drift on the Perito Moreno terrace constructed from detritus eroded from the scarp separating the Nágera and Perito Moreno terraces. Note detached drifts on either side of moat. D=Diapirs. B. Seismic profile across a depression north of Canyon 2. We infer that the morphology displayed by this profile is due to a combination of submarine erosion and subsequent deposition of sediment by bottom currents. $\mathbf{C}$. Plastered drift on both sides of Canyon 3. The stratified sequence below the drift may consist of Paleogene strata. D. 3D view of four linear scarps (dotted lines) along the eastern edge of the Perito Moreno Terrace. These scarps were eroded by north flowing Falkland / Malvinas current and the depressions (white arrows) probably represent potholes carved by the same current. The 3D view shows locations of profiles $4 \mathrm{~B}$ and $\mathrm{C}$. See Fig. 1B for location of profile 4A.

Figure. 5. A. Plastered sediment drifts on the divides between the tributaries of Canyon 4 and the divide between canyons 5 and 4 . B. Sediment drift along the crest of the swell 
along the north side of Canyon 4. V=Vent: $\mathrm{P}=$ Pockmark. C. Gullied sediment drift between canyons 5 and 6 . G=Gullies. See Fig. 1B for locations of profiles.

Figure. 6. $3 \mathrm{D}$ view of the ridge between canyons 2 and 1 showing the locations of the high resolution profiles displayed in Fig. 3B-E High-resolution seismic profiles of the

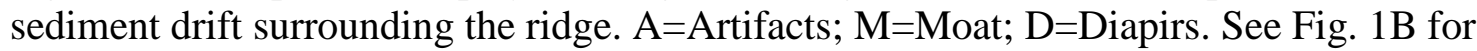
locations of profiles.

Figure. 7. Images of coral gardens at camera station 13 (A-C; $575 \mathrm{~m}$ ). A. Different species of Primnoidae are dominant among Alcyonacea, Gorgonacea, Bryozoa, Ophiuroids (Gorgonocephalidae, Astrotoma sp.), Asteroidea (Henricia sp. and Family Solasteridae), Octopodidae, Ascidians, and Sponges. B. Octocoralia of Family Primnoidae are also dominants species with Ophiura (Ophiuroglypha) lymani, Astrotoma sp., massive sponges and fishes as grenadier (Macrourus carinatus). C. Several species of Octocorallia (including orders Alcyonacea and Gorgonacea) are abundant with representatives of phyla Porifera and Echinodermata $\quad$ D. The photograph at Station 9 (1320 m) images sediments waves developed on pebbly sand sediments by the northerly flowing Falkland / Malvinas Current and glacial erratics with corals. E: Bottom photographs at Station 10 (732 m) displaying a thicket of cold-water corals (Bathelia candida), Octocorals (Family Primnoidae), a specimen of the crab Paralomis sp.

(Crustacea, Lithodidae), bryozoans and some species of Porifera, at the southeast end of the ridge south of Canyon 2. F. In addition to scleractinian Bathelia candida some areas of Station 10 are dominated by Paragorgia spp. (Octocorallia) that provides a multitude of micro-niches for the associated animal community (Porifera, Stylasterids, Hydrozoa, Brachiopoda, Decapoda, Tunicata, and so on). See Fig. 1 for locations of photograph station

Figure. 8. Morpho-sedimentary map of the Patagonian continental shelf and slope. Terrace terminology adopted from Hernández-Molina et al. (2010).

Table I. Summary of the main morphological features of the Patagonian continental slope. 